\title{
MENINGKATKAN HASIL BELAJAR SISWA MENGGUNAKAN METODE PEMBELAJARAN BERBASIS INKUIRI PADA MATA PELAJARAN AKIDAH AKHLAK UNTUK SISWA KELAS VII/1 DI MTS WIRDULLATIFAH NW BANJAR MANIS
}

\author{
Muhammad Syafirin', Muh. Tarmizi Tahir ${ }^{2}$ \\ ${ }^{1}$ STAI Darul Kamal NW Kembang Kerang, ${ }^{2}$ Dosen STAI Darul Kamal NW Kembang Kerang \\ Jl. Pariwisata Kembang Kerang Lotim NTB \\ *Author.1mubammadsyafirin96@gmail.com²tarmizitabir970gmail.com
}

\begin{abstract}
ABSTRAK
Penelitian ini dilakukan untuk meningkatkan hasil belajar siswa pada mata pelajaran Akidah Akhlak pada materi taubat, taat, istiqamah dan ikhlas menggunakan model direct instruction di kelas VII/1 MTs Wirdullatifah NW Banjar Manis. Jenis penelitian ini yaitu Penelitian Tindakan Kelas (PTK) melalui penerapan metode pembelajaran berbasis inkuiri. Dalam pelaksanaannya, penelitian tindakan kelas menggunakan metode pembelajaran berbasis inkuiri dapat meningkatkan hasil belajar siswa pada pembelajaran Akidah Akhlak. Hal ini dapat dilihat dari hasil belajar siswa yang semula pada pra siklus dari 7 siswa hanya ada dua siswa yang tuntas $(28,6 \%)$ dengan nilai rata-rata 66,85, nilai tertinggi 80 dan nilai terendah 50. Dari pra siklus tersebut setelah dilakukan perbaikan pembelajaran pada siklus I ada peningkatan menjadi 4 siswa yang tuntas KBM, nilai rata-rata 73,28\%, nilai tertinggi 85 dan nilai terendah 55. Pada perbaikan pembelajaran siklus II keseluruhan 7 siswa tuntas KBM $100 \%$, nilai rata-rata 83,57\%, nilai tertinggi 90 dan nilai terendah 75.
\end{abstract}

Kata Kunci: Hasil Belajar, Inkuiri, Akidab Akblake

\section{A. PENDAHULUAN}

Hasil belajar bukan hanya dijadikan salah satu indikator yang dapat digunakan untuk mengukur peningkatan mutu belajar seseorang, tetapi juga merupakan pencapaian belajar seseorang baik dari segi kognitif ${ }^{1}$, afektif ${ }^{2}$, maupun psikomotoriknya. ${ }^{3}$ Dalam prosesi belajar mengajar, terdapat banyak faktor yang mempengaruhi pencapaian tersebut. Secara universal, faktor tersebut terbagi dalam dua aspek; pertama faktor internal, kedua faktor eksternal. Faktor internal terkait dengan kedisiplinan, responsif dan insentifitas siswa. Sementara faktor eksternal terdiri dari sarana dan prasarana pembelajaran, seperti lingkungan belajar, tujuan pembelajaran, dan kreatifitas media dan metode pembelajaran. Faktor-faktor tersebut

1 Ranah kognitif berkenaan dengan hasil belajar intelektual yang terdiri dari empat aspek yaitu aplikasi, analisis, sintesis, dan evaluasi.

${ }^{2}$ Ranah afektif berkenaan dengan sikap yang terdiri dari lima aspek yaitu penerimaan, jawaban, penilaian, organisasi, dan internalisasi.

3 Ranah Psikomotorik berkenaan dengan hasil belajar berupa keterampilan dan kemampuan bertindak. Lihat, Maisaroh \& Rostrieningsih, Peningkatan Hasil Belajar Siswa dengan Menggunakan Metode Pembelajaran Active Learning Tipe Quiz Team Pada Mata Pelajaran Keterampilan Dasar Komunikasi di SMK Negeri 1 Bogor, Jurnal Ekonomi \& Pendidikan, Vol. 8 No. 2, November 2010, h. 157. 
merupakan satu kesatuan yang berkelindan sebagai variabel utama yang mendasari hasil atau prestasi belajar siswa. ${ }^{4}$ Untuk mengetahui berhasil atau tidaknya seseorang dalam menguasai ilmu pengetahuan pada suatu mata pelajaran dapat dilihat melalui prestasinya. Peserta didik akan dikatakan berhasil apabila prestasinya baik dan sebaliknya, ia tidak berhasil jika prestasinya rendah. ${ }^{5}$

Dari sekian faktor yang ada, salah satu aspek yang menjadi elan vital bagi seorang guru ialah metode pembelajaran. Penerapan metode yang tepat tentunya akan menghasilkan suasana pembelajaran yang hidup, menyenangkan, bahkan juga memungkinkan siswa untuk mengembangkan kreatifitasnya. Suasana pembelajaran semacam ini, pada akhirnya, tidak hanya dapat meningkatkan kognisi siswa, melainkan juga berimplikasi besar terhadap sikap kedisiplinan mereka. Bukankah kedua aspek tersebut dapat menjadi faktor penentu keberhasilan siswa dalam menggapai hasil belajar yang terbaik?

Dalam efektifitas seorang guru di sekolah, Thomas Gordon menyatakan bahwa, mengajar itu bukan semata persoalan menceritakan, dan 'belajar' bukanlah konsekuensi otomatis dari perenungan informasi yang ditancapkan ke dalam benak siswa. Tetapi, belajar memerlukan peran mental dan kolaborasi siswa sendiri. Penjelasan dan pemeragaan semata tidak akan membuahkan hasil belajar yang maksimal dan langgeng. ${ }^{6}$

Berdasarkan hasil pengamatan penulis di MTs Wirdullatifah NW Banjar Manis khususnya untuk kelas VII semester 1 pelajaran Akidah Akhlak, proses belajar mengajar dilakukan dengan metode konvensional (ceramah). Situasi sarana dan kendala bangunan madrasah yang sedang dalam proses pembangunan demikian menjadi alasan digunakannya metode tersebut. Namun di saat proses pembelajaran tersebut berlansung, tidak sedikit siswa yang sebelum mulai belajar matanya riang terbuka, kemudian perlahan meredup karena rasa kantuk yang menikam. Di samping itu juga, terdapat beberapa siswa yang hanya menjadi 'listener' (pendengar setia) dan tergolong pasif di kelas. Bahkan yang lebih ironisnya lagi, saat mendapat nilai yang kurang memuaskan seakan-akan menjadi tipikal bagi mereka.

Jika kondisi di atas didiamkan begitu saja tanpa adanya rekonstruksi dari seorang guru dalam kreatifitas pengajarannya, maka bagi peneliti, secara dinamis akan menimbulkan tiga macam problem kognisi; pertama, tidak terbangunnya rasa 'ingin tahu' siswa; kedua, sulit terbentuknya kemandirian dalam kegiatan pembelajaran; ketiga, dis-telaten siswa dalam mengembangkan materi yang diterima. Ketiga problem ini tentunya akan menghambat hasil dan tujuan kegiatan pembelajaran sesuai dengan ekspektasi pendidikan.

Berdasarkan atas latar belakang di atas, maka peneliti tertarik untuk melakukan penelitian tindakan kelas (PTK) berkaitan dengan peningkatan motivasi dan hasil belajar siswa dengan menerapkan salah satu metode pembelajaran, yaitu pembelajaran berbasis inkuiri untuk

${ }^{4}$ Hasil belajar atau yang dikenal sebagai prestasi pembelajaran merupakan hasil penilaian pendidik terhadap proses belajar dan hasil belajar siswa sesuai tujuan instruksional yang menyangkut isi pelajaran (pengetahuan) dan perilaku (keterampilan dan sikap) yang diharapkan dari siswa. Lihat, B.B Wiyono, Teori Hasil Belajar, (Jakarta: Gramedia, 2009), h. 73.

${ }^{5}$ husairi. (2021). UPAYA MENINGKATKAN HASIL BELAJAR KOGNITIF BAHASA ARAB MELALUI MEDIA GAMBAR PADA PESERTA DIDIK KELAS IV MI NW 1 KEMBANG KERANG. Alifbata: Jurnal Pendidikan Dasar, 1(1), 10-36. https://doi.org/10.51700/alifbata.v1i1.103

6 Thomas Gordon, Guru Yang Efektif, Cara Mengatasi Kesulitan Dalam Kelas, (Jakarta: CV Rajawali, 1984), h. 60. 
mengungkapkan apakah dengan basis ini dapat meningkatkan motivasi dan hasil belajar Akidah Akhlak di kelas VII-1 MTs. Wirdullatifah NW Banjar Manis.

Pengajaran berbasis inkuiri, sebetulnya, dibangun dengan asumsi bahwa setiap manusia memiliki dorongan untuk menemukan sendiri pengetahuannya. Rasa keingin tahuan tersebut merupakan suatu kodrat sejak ia terlahir ke dunia, baik melalui indra penglihatan, pendengaran dan panca indra lainnya. Hasrat 'ingin tahu' nya manusia ini terus berlanjut hingga ia berkembang menjadi dewasa dan dapat menggunakan akal pikirannya untuk menemukan jawaban atas rasa keingin tahuannya itu. ${ }^{7}$

Tujuan utama pembelajaran berbasis inkuiri adalah membantu siswa untuk dapat mengembangkan disiplin intelektual dan keterampilan berpikir dengan memberikan pertanyaan-pertanyaan dan mendapatkan jawaban atas dasar ingin tahu mereka. Sehingga dalam metode ini, siswa harus lebih aktif dalam memecahkan dan menemukan persoalan. Mereka ditekankan berpikir kritis dan analitis untuk mencari dan menemukan sendiri jawaban dari suatu masalah yang dipertanyakan. Sementara guru sebagai pemberi arahan dan petunjuk dalam memecahkan persoalan tersebut. ${ }^{8}$

Dengan demikian, dalam prosesi belajar-mengajar, guru tidak lagi mendominasi lazimnya seperti kegiatan pembelajaran yang dilakukan sebelumnya, melainkan siswa dituntut untuk berbagi informasi dengan siswa lainnya dan saling belajar-mengajar satu sama lain. Dengan begitu, keberhasilan belajar akan lebih meningkat karena sebagian besar siswa terlibat aktif dalam proses pembelajaran, dan dalam sistem ini seorang guru bertindak sebagai fasilitator dan pemberi petunjuk.

Pada akhirnya, metode pembelajaran berbasis inkuiri diharapkan dapat memberikan urgensi pada tiga hal utama; pertama, siswa mendapat pengalaman baru yang dengannya dapat menumbuhkan semangat dalam belajar; kedua, menciptakan prosesi pembelajaran yang aktif, dan bervariatif, sehingga siswa tidak lagi pasif, jenuh bahkan ngantuk dengan pembelajaran tersebut; ketiga, dapat meningkatkan hasil belajar kognitif siswa dalam mata pelajaran Akidah Akhlak.

\section{B. METODE PENELITIAN}

Penelitian ini tergolong analisis deskriptif PTK (Penelitian Tindakan Kelas), yakni studi yang digunakan untuk mengumpulkan, mengolah, menganalisis, menginterpretasi dan menyimpulkan data sehingga memperoleh gambaran yang sistematis dalam peningkatan aktivitas pembelajaran. Karakter penelitian tindakan kelas (PTK) adalah: 1) Didasarkan atas problem aktual yang dihadapi guru dalam proses pengajaran; 2) Peneliti melakukan kolaborasi melalui kerjasama dengan pihak lain; 3) Peneliti melakukan refleksi; 4) Memecahkan permasalahan dengan tujuan meningkatkan mutu pembelajaran; 5) Dilakukan dalam rangkaian tahapan siklus. ${ }^{9}$

7 Winarno Surakhmat, Metodologi Pengajaran Nasional, (Bandung: Penerbit Jemmars, 1980), h. 81. Pernyataan ini sejalan dengan pandangan Thomas Gordon yang menegaskan bahwa hasil pembelajaran yang langgeng hanya akan akan diperoleh dari kegiatan pengajaran berbasis inkuiri, lihat Thomas Gordon, Guru Yang Efektif...h. 60.

${ }^{8}$ Nana Sudjana, Penilaian Hasil Proses Belajar Mengajar, (Bandung: Penerbit PT. Remaja, 1989), h. 73.

9 Zamria, Upaya Peningkatan Prestasi Belajar Akidah Akblak Melalui Metode Cooperative Script Untuk Siswa MTs.N 1 Baubau, Jurnal Inovasi Penelitian Tindakan Kelas dan Sekolah, Vol. 1 No. 1 Juli 2021, h. 98-99. 
Metode penelitian yang digunakan dalam penelitian ini adalah model analisis Kurt Lewin yang diperkenalkannya semenjak tahun 1946. Lexy J. Moleong menyebutkan empat tahapan dalam prosedur analisis Lewin, antara lain: ${ }^{10}$

\section{Planning (Perencanaan)}

Tahap perencanaan terdiri dari; (a) mempelajari kurikulum keterampilan dasar (KD) dan buku ajar untuk mempersiapkan bahan pengajaran serta membuat Rencana Pelaksanaan Pembelajaran (RPP); (b) peneliti menyusun teknis pelaksanaan kegiatan pembelajaran berbasis inkuiri yang dilaksanakan pada pertemuan pertama dimulainya penelitian tindakan kelas; (c) selama proses pembelajaran berlansung akan diterapkan variasi, khususnya pada saat pelaksanaan metode inkuiri; (d) peneliti menyusun ringkasan materi yang akan diajarkan untuk setiap pokok bahasan; (e) mempersiapkan soal-soal cadangan, sebagai antisipasi kemungkinan jika siswa tidak mempersiapkan soal.

2. Action (Pelaksanaan)

Tahap ini terdiri dari; pemberian bahan ajar yang berkaitan dengan materi yang akan diajarkan. Kemudian peneliti membentuk tim kelompok yang sebelumnya sudah ditentukan terlebih dahulu oleh kolaborator dan peneliti. Selanjutnya peneliti memberikan materi tentang bahasan yang akan dipelajari, namun sebelum peneliti menjelaskan materi, peneliti biasanya memberikan apersepsi untuk mengetahui sejauh mana pemahaman siswa terhadap materi ajar sebelumnya. Setelah itu, peneliti meminta salah satu tim kelompok untuk menyiapkan kuis jawaban singkat dari materi yang telah dipelajari, sementara tim yang lain menggunakan waktu ini untuk memeriksa catatan mereka. Hingga pada akhir kuis selesai, lalu peneliti memberikan post test untuk mengetahui tingkat keberhasilan dari setiap kegiatan pembelajaran yang telah dilakukan di siklus pertama.

\section{Observing (Pengamatan)}

Pada tahap ini, peneliti melakukan dokumentasi atas proses kegiatan dan keadaan pembelajaran serta faktor-faktor lain yang timbul dan berkembang selama pelaksanaan tindakan. Kemudian hasil dokumentasi tersebut dijadikan sebagai dasar melakukan refleksi dalam merencanakan tindakan berikutnya. Selain itu seorang kolaborator juga mesti mengamati situasi selama prosesi pembelajaran berlansung dan mendeskripsikannya pada lembaran kolaborator. Dalam hal ini, aspek utama yang dinilai adalah perkembangan keaktifan siswa selama proses pembelajaran berlansung.

4. Reflection (Refleksi) ${ }^{11}$

${ }^{10}$ Lexy J. Moleong, Metode Penelitian Kualitatif, (Bandung: PT Remaja Rosda Karya, 2013), h. 82.

11 Model penelitian tidakan kelas (PTK) atau dalam bahasa Inggrisnya "Classroom Action Research" yang diperkenalkan Kurt Lewin pada tahun 1946 ini, selanjutnya dikembangkan oleh beberapa pakar, seperti Stephen Kemmis, Robin Mc. Taggart, John Elliot, Dave Ebbutt dan lainnya. Pada awalnya, penelitian tindakan menjadi salah satu model penelitian yang dilakukan pada pekerjaan tertentu di mana peneliti melakukan pekerjaannya, baik di bidang pendidikan, kesehatan maupun pengelolaan sumber daya manusia (SDM). Lihat, Dahlia S. Penelitian Tindakan Kelas, (Palu: Edukasi Mitra Grafika, 2012), h. 92. 
Pada tahap ini, peneliti berkolaborasi bersama kolaborator merenungkan serta mengevaluasi kembali, apakah rencana dengan pelaksanaan serta proses tindakan telah dilakukan dengan baik. Apabila hasil dari observasi dan refleksi pada siklus pertama akan menjadi acuan dasar untuk perencanaan tindakan pada siklus berikutnya, sehingga tindakan pada masing-masing siklus akan berbeda sesuai dengan kekurangan pada siklus sebelumnya. Adapun untuk menentukan ketuntasan hasil belajar klasikal dapat dihitung dengan menggunakan rumus:

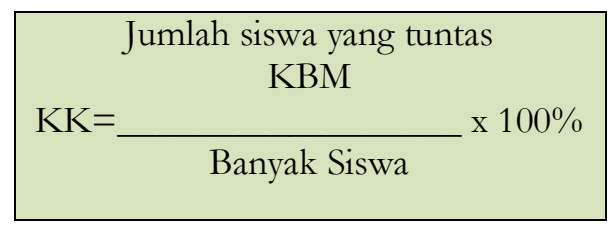

Berdasarkan hasil dari teknik analisis data, maka peneliti menentukan penelitian dianggap berhasil apabila hasil belajar peserta didik telah mencapai $\geq 71 \%$ ketuntasan klasikal (KK) menggunakan rumus rata-rata seperti dicantum di atas.

Selanjutnya teknik pengumpulan data yang penulis gunakan dalam penelitian ini adalah: (1) observasi, yakni mengamati secara lansung dengan teliti, cermat serta hati-hati terhadap fenomena pelajaran Akidah Akhlak dengan menggunakan metode inkuiri. (2) Catatan lapangan yang dipakai berupa pernyataan semua peristiwa yang dialami dan didengar. (3), wawancara, yang digunakan untuk mendapatkan gambaran problem yang jelas. (4) Teknik dokumentasi, berupa nama-nama siswa. (5) Metode tes, digunakan untuk memperoleh data tentang motivasi dan hasil belajar siswa sebelum penelitian, selama penelitian dan setelah penelitian. Kemudian analisis datanya dilakukan sejak tindakan pembelajaran dilakukan selama proses refleksi sampai selesai.

Selain itu, penelitian ini dilakukan melalui fase siklus. Siklus tersebut akan terus berulang sehingga membentuk spiral. Banyaknya siklus yang diterapkan tergantung pada peningkatan hasil belajar siswa. Siklus akan berhenti dilakukan bilamana siswa telah mengalami peningkatan hasil belajarnya. Maka dalam penelitian ini penulis melakukan 2 kali siklus tindakan, yakni siklus I, siklus II.

\section{HASIL PENELITIAN}

Penelitian berjalan dalam rentang waktu 3 (tiga) minggu dalam 6 kali pertemuan ( 12 jam pelajaran x 40 menit) mencakup keseluruhan tahapan yang diperlukan dalam penelitian, mulai dari tahap persiapan, tahap pelaksanaan hingga tahap penulisan laporan. Adapun terkait jadwal, penelitian ini dilaksanakan mulai dari tanggal 18 Oktober sampai dengan 08 November 2021. Setiap siklus penelitian terdiri dari 4 (empat) tahap kegiatan utama, yaitu perencanaan, tindakan, pengamatan dan refleksi.

Berdasarkan atas rangkaian penelitian yang telah dilakukan di kelas VII semester 1 MTs Wirdullatifah NW Banjar Manis, ditemukan hasil penelitian yang menunjukkan hasil belajar siswa di mulai dari fase pra siklus, kemudian siklus I, dan siklus II. Data-data yang didapatkan dari setiap fase tersebut dapat diklasifikasikan dalam tebel di bawah ini.

Tabel 1. Data Hasil Pra Siklus, Siklus I, Silus II

\begin{tabular}{|l|l|l|l|l|}
\hline No & Nama & Pra & Siklus & Siklus \\
\hline
\end{tabular}




\begin{tabular}{|c|c|c|c|c|}
\hline & Siswa & Siklus & I & II \\
\hline 1 & A1 & 65 & 70 & 80 \\
\hline 2 & A2 & 50 & 55 & 75 \\
\hline 3 & A3 & 68 & 75 & 85 \\
\hline 4 & A4 & 80 & 85 & 90 \\
\hline 5 & A5 & 75 & 80 & 90 \\
\hline 6 & A6 & 60 & 70 & 80 \\
\hline 7 & A7 & 70 & 78 & 85 \\
\hline Nilai Rata-Rata (\%) & $66,85 \%$ & $73,28 \%$ & $83,57 \%$ \\
\hline \multicolumn{2}{|c|}{ Ketuntasan (\%) } & $28,6 \%$ & $57,1 \%$ & $100 \%$ \\
\hline
\end{tabular}

\section{PEMBAHASAN}

\section{Kondisi Pra Siklus}

Kondisi pra siklus merupakan kondisi dimana siswa belum memperoleh perlakuan penelitian tindakan. Rangkaian pembelajaran yang digunakan di dalam kelas VII MTs Wirdullatifah NW Banjar Manis belum menggunakan metode pembelajaran berbasis inkuiri. Sebelum melakukan penelitian, penulis terlebih dahulu melakukan sebuah pengamatan terhadap situasi kelas, siswa dan guru selama proses pembelajaran. Dalam pengamatan tersebut, penulis melihat lebih banyak siswa tidak memperhatikan penjelasan guru dibanding yang serius dan aktif dalam proses pembelajaran. Siswa juga tidak aktif saat berdiskusi dengan guru, bahkan terkadang mereka bingung apa yang mesti didiskusikan pada saat itu. Hal ini menunjukkan bahwa tingkat antusias belajar mereka belum mulai tampak, sehingga tentunya yang demikian ini akan berimplikasi pada nilai atau hasil belajar mereka.

Metode yang digunakan pada saat pembelajaran di kelas adalah metode konvensional (ceramah), dimana guru bertindak sebagai sumber utama, sedangkan siswa bertindak hanya sebagai pendengar (listener). Dengan metode ceramah ini, ternyata hasil yang diperoleh kurang memuaskan, di samping tingkat pemahaman siswa tidak tumbuh selama proses pembelajran, dimana rata-rata hasil belajar mata pelajaran Akidah Akhlak yang rendah yaitu 66,14\%. Hal ini dapat diketahui dari hasil tes pra siklus siswa yang belum mencapai KBM (Ketuntasan Belajar Minimal) yang ditetapkan madrasah yaitu $71 \%$. Secara nominal, kuantitas siswa yang belum tuntas belajar tergolong rendah yaitu 5 siswa, sedangkan yang tergolong tuntas hanya 2 siswa saja. Hasil belajar pada fase pra siklus dapat dilihat dalam grafik berikut.

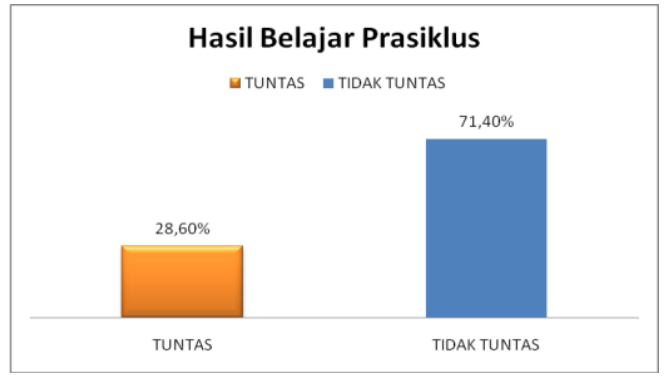

Grafik 1. Persentase hasil belajar pra siklus 
Berdasarkan grafik di atas, terdapat 2 orang yang telah mencapai kriteria keberhasilan yaitu $28,60 \%$ dan telah melebihi target KBM $71 \%$, sedangkan 5 siswa $(71,40 \%)$ belum mencapai kriteria keberhasilan atau kurang dari target nilai KBM 71\%.

\section{Pelaksanaan Tindakan Siklus I}

a. Tahap perencanaan

Sebelum melakukan tindakan, peneliti mempersiapkan Rencana Pelaksanaan Pembelajaran (RPP) untuk dua kali pertemuan yaitu 4 x 40 menit. Materi pembelajaran pada siklus I adalah taubat dan taat. Selain itu juga, penulis mempersiapkan mempersiapkan instrumen-instrumen yang dibutuhkan dalam penelitian, yaitu lembar observasi kegiatan siswa, kreatifitas guru, dan soal post test.

\section{b. Tahap pelaksanaan}

Pelaksanaannya dilaksanakan sebanyak dua kali pertemuan yaitu pertemuan pertama pada hari Senin 18 Oktober 2021, dan pertemuan kedua pada hari Sabtu tanggal 23 Oktober 2021. Setiap pertemuan berlansung selama 80 menit. Pada pertemuan ini, peneliti melakukan pengkondisian kelas yaitu dengan merapikan cara duduk siswa kemudian mengabsen semua siswa sebagai perkenalan awal. Selanjutnya peneliti memulai menyampaikan materi pembelajaran dengan terlebih dahulu menyampaikan apersepsi materi yang telah dipelajari pada minggu yang lalu dan memberikan contoh-contoh mengenai perilaku taubat dan taat.

Selanjutnya masuk pada kegiatan inti pembelajaran, peneliti membentuk 3 kelompok yang beranggotakan 2 orang kecuali ada satu kelompok yang terdiri dari 3 orang. Masingmasing kelompok diberikan materi yang berbeda-beda dan setiap kelompok mendiskusikan sub bab dari materi tentang taubat. Setelah selesai berdiskusi, perwakilan setiap kelompok mempersentasikan hasil dari kesimpulan yang didapat. Peneliti dan peserta didik mengambil intisari penjelasan tersebut.

\section{c. Tahap observasi}

Fungsi observasi adalah mendokumentasikan pengaruh tindakan yang terkait. Pada proses pembelajaran siklus I masih ditemukan beberapa kekurangan yaitu sulitnya mengondisikan siswa karena belum terlalu akrab dengan peneliti. Kemudian pada saat menjelaskan materi pembelajaran, beberapa siswa masih ada yang bermain dan tidak memperhatikan materi pembelajaran. Selain itu, kurang aktifnya beberapa siswa ketika kegiatan diskusi sedang berlansung.

\section{d. Tahap refleksi}

Pada tahapan ini, peneliti bersama dengan guru mata pelajaran yang bertugas sebagai kolaborator dan observer menganalisis sekaligus mengevaluasi proses pembelajaran pada siklus I, apakah tindakan yang telah diberikan sudah sesuai atau belum dengan konsep penelitian yang telah direncanakan sebelumnya. Kemudian hasil penelitian siklus I dibandingkan dengan indikator keberhasilan. Tahap refleksi ini dilakukan dengan tujuan untuk memperbaiki dan menyempurnakan tindakan yang akan diberikan pada siklus berikutnya, yakni siklus II. 
Pada siklus ini terdapat beberapa hal yang harus diperbaiki, antara lain sebelum proses pembelajaran Akidah Akhlak guru harus membangkitkan semangat dan motivasi siswa-siswanya agar dapat mengikuti pelajaran dengan baik. Kemudian guru harus bisa memberikan sikap tegas kepada siswa yang sering bercanda ketika guru sedang menjelaskan materi pelajaran. Selain itu, pada saat kegiatan diskusi sedang berlansung, guru harus memberikan peraturan kepada siswa agar setiap siswa berperan aktif dalam kegiatan diskusi dalam kelompoknya. Hal ini dapat dilakukan dengan memberikan pengurangan nilai bagi siswa yang tidak aktif dan bercanda ketika diskusi sedang berjalan. Adapun hasil belajar siswa pada siklus I dapat diklasifikasikan dalam grafik berikut.

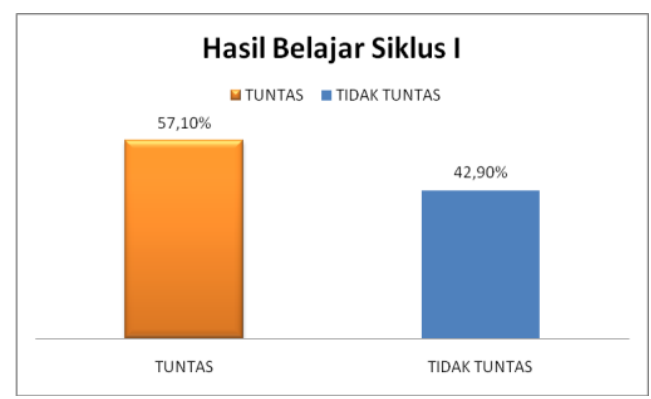

Grafik 2. Persentase hasil belajar Siklus I

Grafik di atas merupakan hasil belajar siswa pada materi taubat dan taat. Adapun hasilnya adalah terdapat 4 orang siswa yang telah mencapai nilai yang bagus yaitu $\geq 75 \%$ dengan nilai rata-rata ketuntasan 57,10\% dan telah melebihi target KBM 71\%, sedangkan 3 siswa (42,90\%) belum mencapai kriteria keberhasilan atau kurang dari target nilai KBM $71 \%$. Hasil persentase ketuntasan pada siklus I ini menunjukkan adanya peningkatan hasil belajar siswa jika dibandingkan dengan nilai pada kondisi pra siklus. Tetapi hasil belajar pada fase ini belum menampakkan hasil yang maksimal karena masih terdapat beberapa siswa yang tidak lulus dari terget nilai KBM. Oleh karena itu, diperlukan lagi pelaksanaan siklus II untuk melengkapi kekurangan hasil belajar pada siklus I.

\section{Pelaksanaan Tindakan Siklus II}

Untuk memperbaiki kekurangan pada siklus I maka dilakukan tindakan pembelajaran selanjutnya pada siklus II yang bertujuan untuk memperbaiki dan menyempurnakan tindakan yang telah dilakukan pada siklus I.

a. Tahap Perencanaan

Tahap perencanaan pada siklus II didasarkan pada hasil refleksi dari tindakan yang dilakukan pada siklus I. Sebelum melakukan tindakan pada siklus I, di tahap ini peneliti membuat Rencana Pelaksanaan Pembelajaran (RPP) untuk dua kali pertemuan dalam durasi 4 x 40 menit. Materi pembelajaran pada siklus ini adalah 'istiqamah' dan 'ikhlas'. Selain itu juga peneliti mempersiapkan instrumen-instrumen yang dibutuhkan dalam penelitian, yaitu media pembelajaran, lembar observasi aktivitas siswa dan guru, serta lembaran soal post test.

b. Tahap Pelaksanaan 
Pelaksanaannya dilaksanakan sebanyak dua kali pertemuan yaitu pertama pada hari Senin 25 Oktober 2021, dan kedua pada hari Sabtu tanggal 30 Oktober 2021. Setiap pertemuan berlansung selama 80 menit dengan materi istiqamah dan ikhlas. Pada tahap pelaksanaan ini tindakan yang peneliti lakukan yaitu melaksanakan kegiatan pembelajaran sesuai dengan Rencana Pelaksanaan Pembelajaran (RPP) yang telah dibuat pada tahap perencanaan sesuai refleksi pada siklus I. Tahap kali ini tidak jauh berbeda dengan aktivitas yang dilakukan pada siklus I yaitu memastikan kondisi kelas sudah siap untuk belajar, melakukan presensi, mengulas kembali materi yang telah dibahas pada pertemuan sebelumnya.

Selanjutnya peneliti meminta siswa untuk membentuk kelompok seperti minggu sebelumnya, kemudian menyimak video yang berisi materi tentang istiqamah dan ikhlas. Setelah itu, peneliti memberikan sub bab materi yang berbeda-beda untuk didiskusikan bersama kelompok masing-masing. Sampai pada akhir pertemuan, peneliti memberikan post test atau tes hasil belajar siklus II berkaitan dengan materi yang telah dipelajari, yang bertujuan untuk mengetahui sejauh mana siswa telah menguasai materi pelajaran yang telah diajarkan dan juga untuk mengetahui seberapa besar manfaat dari penerapan metode inkuiri dalam meningkatkan motivasi dan hasil belajar siswa. Setelah tes selesai, peneliti menutup pelajaran.

c. Tahap Observasi

Pada tahap observasi siklus II sama seperti pada siklus I yaitu dilaksanakan pada saat proses pembelajaran berlansung, di mana guru mengobservasi proses pembelajaran dengan menggunakan metode inkuiri sekaligus mengamati aktivitas siswa dan peneliti selaku pengajar dengan melakukan dokumentasi serta menilai hasil belajar siswa setelah post test. Berdasarkan hasil pengamatan diharapkan nilai tes hasil belajar dapat meningkat.

d. Tahap Refleksi

Pada tahap ini, peneliti bersama dengan guru mata pelajaran menganalisis sekaligus mengevaluasi kembali proses pembelajaran pada siklus II, apakah tindakan yang telah diberikan sudah sesuai atau belum dengan konsep penelitian yang telah direncanakan di awal. Kemudian hasil penelitian siklus II dibandingkan dengan indikator keberhasilan. Berdasarkan pengamatan pada siklus II, dapat diperoleh gambaran bahwa proses pembelajaran Akidah Akhlak dengan metode inkuiri sudah berjalan dengan baik dan memberikan efek positif yang maksimal terhadap siswa kelas VII MTs Wirdullatifah, sehingga seluruh hasil belajar siswa masuk dalam standar KBM. Hal tersebut dibuktikan dengan hasil belajar Akidah Akhlak siswa pada tahap siklus II. Peneliti merasa tindakannya telah mencapai indiaktor keberhasilan secara maksimal, sehingga rangkaian tindakan dicukupkan sampai siklus II. 


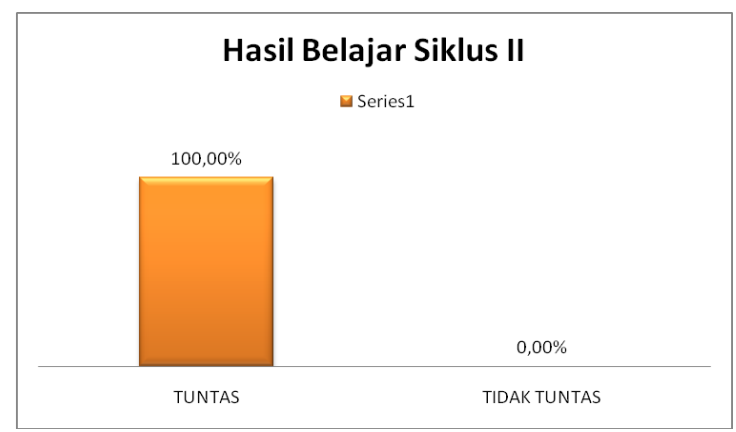

Diagram 3. Persentase hasil belajar Siklus II

Hasil belajar Akidah Akhlak pada siklus II mengalami peningkatan yang signifikan dibanding dengan siklus sebelumnya. Semua siswa berhasil (100\%) menggapai kriteria ketuntasan standar nilai KBM dengan nilai rata-rata 83,57\%. Hal ini menandakan bahwa metode pembelajaran berbasis inkuiri telah berhasil meningkatkan hasil belajar siswa pada kelas VII semester 1 MTs Wirdullatifah Banjar Manis.

Tabel 2. Hasil Belajar Pra Siklus, Siklus I, Siklus II

\begin{tabular}{|c|c|c|c|c|}
\hline No & Uraian & $\begin{array}{c}\text { Kondisi } \\
\text { Pra Siklus }\end{array}$ & Siklus I & Siklus II \\
\hline 1. & $91-100$ & 0 & 0 & 0 \\
\hline 2. & $81-90$ & 0 & 1 & 4 \\
\hline 3. & $71-80$ & 2 & 3 & 3 \\
\hline 4. & $<71$ & 5 & 3 & 0 \\
\hline
\end{tabular}

Tabel 3. Persentase Hasil Belajar Pra Siklus, Siklus I, Siklus II

\begin{tabular}{|c|c|c|c|c|}
\hline No & Uraian & $\begin{array}{c}\text { Kondisi Pra } \\
\text { Siklus }\end{array}$ & Siklus I & Siklus II \\
\hline 1. & Nilai Terendah & 50 & 55 & 75 \\
\hline 2. & Nilai Tertinggi & 80 & 85 & 90 \\
\hline 3. & Nilai Rata - Rata & $66,85 \%$ & $73,28 \%$ & $83,57 \%$ \\
\hline 4. & Ketuntasan & $28,6 \%$ & $57,1 \%$ & $100 \%$ \\
\hline
\end{tabular}

\section{E. SIMPULAN DAN SARAN}

\section{Simpulan}

Berdasarkan pada hasil penelitian pelaksanaan tindakan yang telah dilakukan dalam penerapan metode pembelajaran berbasis inkuiri pada mata pelajaran Akidah Akhlak di kelas VII/1 MTs. Wirdullatifah NW Banjar Manis, maka dapat ditarik kesimpulan sebagai berikut:

a. Sebelum adanya penerapan metode pembelajaran berbasis inkuiri di kelas, terlihat hanya segelintir siswa yang aktif, siswa kurang antusias mengikuti jalannya proses pembelajaran dan hasil belajar siswa pada mata pelajaran Akidah Akhlak pun rendah atau di bawah standar KBM. 
b. Penerapan metode pembelajaran berbasis inkuiri dapat meningkatkan kemampuan siswa secara optimal pada mata pelajaran Akidah Akhlak di MTs. Wirdullatifah NW Banjar Manis.

c. Peningkatan hasil belajar siswa dapat dicapai, hal ini dapat dilihat dari adanya peningkatan nilai belajar siswa. Sebelumnya, pada hasil pra siklus hanya 2 siswa yang memenuhi nilai KBM dan rata-rata hasil belajar sebesar $66,85 \%$ dengan persentase ketuntasan $28,6 \%$. Namun, di siklus I mulai meningkat dengan rata-rata hasil belajar siswa yaitu 73,28\% dengan persentase kelulusan jumlah siswa yang telah mencapai KBM mencapai 57,1\%. Kemudian, di siklus II rata-rata hasil belajar siswa meningkat lagi yaitu 83,57\% dengan persentase kelulusan 100\%. Data ini menunjukkan bahwa metode pembelajaran berbasis inkuiri telah berhasil membantu siswa untuk memenuhi Ketuntasan Belajar Minimal (KBM) sebesar $71 \%$.

d. Penerapan metode pembelajaran berbasis inkuiri telah mampu meningkatkan hasil belajar siswa, sebab kreativias yang diberikan membuat mereka tertarik, senang dan semangat dalam belajar dan menjawab test soal.

\section{Saran}

a. Berdasarkan hasil penelitian yang dilakukan, peneliti memberi saran bahwa penelitian tindakan kelas (PTK) sangat perlu dilakukan dalam kegiatan proses pembelajaran, karena merupakan tindakan nyata yang dilakukan untuk mengatasi persoalan yang terdapat dalam pembelajaran di kelas.

b. Bagi guru mata pelajaran Akidah Akhlak disarankan untuk terus mendorong semangat dan motivasi siswa dalam belajar agar dapat meningkatkan mutu proses, hasil pembelajaran dan mengatasi masalah pembelajaran. Dan diharapkan juga guru memiliki beberapa variasi metode pembelajaran yang dapat diterapkan di kelas. Salah satunya dengan menggunakan metode inkuiri. 


\section{DAFTAR PUSTAKA}

Dahlia, S. (2012). Penelitian Tindakan Kelas. Palu: Edukasi Mitra Grafika.

Gordon, T. (1984). Guru Yang Efektif, Cara Mengatasi Kesulitan Dalam Kelas. Jakarta: CV Rajawali.

husairi. (2021). UPAYA MENINGKATKAN HASIL BELAJAR KOGNITIF BAHASA ARAB MELALUI MEDIA GAMBAR PADA PESERTA DIDIK KELAS IV MI NW 1 KEMBANG KERANG. Alifbata: Jurnal Pendidikan Dasar, 1(1), 10-36. https://doi.org/10.51700/alifbata.v111.103

Maisaroh, \& Rostrieningsih. (November 2010). Peningkatan Hasil Belajar Siswa dengan Menggunakan Metode Pembelajaran Active Learning Tipe Quiz. Team Pada Mata Pelajaran Keterampilan Dasar Komunikasi di SMK Negeri 1 Bogor. Jurnal Ekonomi \& Pendidikan, Vol. 8 No. 2.

Moleong, L. J. (2013). Metode Penelitian Kualitatif. Bandung: PT Remaja Rosda Karya.

Sudjana, N. (1989). Penilaian Hasil Proses Belajar Mengajar. Bandung: Penerbit PT. Remaja.

Surakhmat, W. (1980). Metodologi Pengajaran Nasional. Bandung: Penerbit Jemmars.

Wiyono, B. (2009). Teori Hasil Belajar. Jakarta: Gramedia.

Zamria. (Juli 2021). Upaya Peningkatan Prestasi Belajar Akidah Akhlak Melalui Metode Cooperative Script Untuk Siswa MTs.N 1 Baubau. Jurnal Inovasi Penelitian Tindakan Kelas dan Sekolah, Vol. 1 No. 1. 